\title{
Derleme
}

\section{Bisfenol A (BFA) ve insan üreme sağlığı}

\author{
Saniye Sözlü̈1, Yasemin Akdevelioğlu1 \\ ${ }^{1}$ Gazi Üniversitesi, Sağlık Bilimleri Fakültesi, Beslenme ve Diyetetik Bölümü, Ankara.
}

\begin{abstract}
Öz
Bugün yaşantımızın her anında yer alan plastikler neredeyse tüm ürünlerin içerisinde bulunmaktadır. Plastik üretiminde yaygın bir şekilde kullanılan Bisfenol A (BFA), östrojeni taklit ederek endokrin bozucu gibi davranıp insan üreme sağlı̆̆ üzerinde olumsuz etkilere yol açmaktadır. Bu çalışma, BFA'nın üreme sağlığına olan potansiyel etkisini Pubmed veri tabanı kullanılarak bugüne kadar yayınlanan insan temelli çalışmaları inceleyip değerlendirmek amacıyla yapılmıștır. İncelenen literatür sonucunda BFA maruziyetinin ovaryan cevapta, in vitro fertilizasyon (IVF) ve fertilizasyon başarısında azalma, embriyo kalitesi ve sperm kalitesinde düşme, cinsiyet hormon konsantrasyonlarında değişme, erkek cinsel işlev bozukluğu, polikistik over sendromu (PCOS) ile ilişkili olabileceğini göstermektedir. Çalışmaların sonuçları değerlendirildiğinde, BFA maruziyetinin azaltılması (hazır ambalajlı ürünler, plastik kaplar vb. kullanımının azaltılması gibi) hastalıkların önlenmesinde koruyucu bir faktör olabilir. İnsan üreme sağlığı üzerindeki etki mekanizmalarını daha iyi anlamak ve erken aşamalardaki potansiyel üreme toksisitesini tespit etmek için ileri çalışmalara ihtiyaç vardır.
\end{abstract}

Anahtar Sözcükler: Endokrin bozucu, Bisfenol A, üreme sağlı̆̆ı, infertilite

\section{Bisphenol A (BPA) and human reproductive health}

Today, plastics are found in almost all products. Bisphenol A (BPA), widely used in the production of plastics, acts as an endocrine disrupter by imitating estrogen and causes adverse effects on human reproductive health. This study was conducted to investigate and evaluate the potential impact of BPA on reproductive health using human-based studies published up to now using the Pubmed database. The literature review shows that BPA exposure may be associated with decreased ovarian response, in vitro fertilization (IVF) and fertilization success, embryo quality, male sexual dysfunction, decreased sperm quality, changes in sex hormone concentrations, and PCOS. When the results of studies are evaluated, reduction of BPA exposure (such as the use of prepackaged products, plastic containers, etc.) may be a protective factor in the prevention of diseases. Further work is needed to better understand the mechanisms of action on human reproductive health and to detect potential reproductive toxicity at early stages.

Key words: Endocrine disruptors, Bisphenol A, reproductive health, infertility

Yazının geliş tarihi:23.07.2017 Yazının kabul tarihi:26.10.2017

Sorumlu Yazar: Araş. Gör. Saniye Sözlü, Gazi Üniversitesi Sağlık Bilimleri Fakültesi, Beslenme ve Diyetetik Böl., Emniyet Mah. Muammer Yaşar Bostancı Cad. No:16 Beşevler/ Ankara

Tel: 05417733262

E-posta: saniyekoyuncu05@gmail.com 


\section{Giriş}

Dünya genelinde toksik çevresel kontaminantların en belirgin olanlarından birisi olan Bisfenol A [(2.2-bis (4hidroksifenol) propan) BFA] endokrin bozucu olarak bilinmektedir. ${ }^{1}$ BFA ilk olarak 1891'de sentezlenmiştir ${ }^{2}$ ve kimyasal formülü $\mathrm{C}_{15} \mathrm{H}_{16} \mathrm{O}_{2}$ veya $\left(\mathrm{CH}_{3}\right)_{2} \mathrm{C}\left(\mathrm{C}_{6} \mathrm{H}_{4} \mathrm{OH}\right)_{2}$ şeklinde ifade edilmektedir. ${ }^{3}$

BFA, polikarbon ve epoksi gibi reçinelerin üretimine katılarak plastik üretiminde yaygın bir şekilde kullanılmaktadır. Bugün yaşantımızın her anında yer alan plastikler neredeyse tüm ürünlerin içerisinde bulunmaktadır. ${ }^{4}$ Başlıca yiyecek ve içecek kaplarının iç yüzey kaplamalarında, besin kapları, su şişeleri, medikal araçlar, bazı diș dolgu macunlarında ve dolgularında, deterjanlarda, sabunlarda, losyonlarda, şampuanlarda, klimalarda, tırnak parlatıcılarında ve dayanıklı materyallerden yapılması gereken diğer objelerin üretiminde kullanılmaktadır.5,6 Tüm dünyada bir yılda 3.5 milyon tonun üzerinde BFA üretilmekte ve 100 tondan fazlası da atmosfere verilmektedir. ${ }^{7}$ Salınan BFA kalıntıları havada, içme sularında, göllerde, denizlerde, lağımlarda, toprakta, ev tozlarında, gida maddelerinde, kâğıt paralarda ve diğer pek çok obje başta olmak üzere tüm çevrede yaygın bir şekilde bulunmaktadır. ${ }^{8}$ Çevrede bu kadar yaygın olarak bulunan BFA'ya farklı şekillerde maruz kalınabilmektedir. BFA'ya temelde çevresel, tıbbi (kontamine araç ve gereçler) ve mesleki (nefes yoluyla, deri teması ve üretim işlemleri sırasında yutma) ${ }^{9}$ yollar ile maruz kalınsa da BFA'nın insan vücuduna en yaygın giriş yolu kontamine olmuş gıda ve içme sularının tüketilmesi ile olmaktadır. Besinleri pişirmeden veya isıl işlem görmeden önce plastik poşetlere sarmak, mikrodalgaya uygun olmayan kaplar ile besinlerin mikrodalgada ısıtılması veya pişirilmesi gibi yapılan bazı uygulamalar BFA maruziyetini arttırabilir. ${ }^{10}$

Çeşitli yollar ile insanlara bulaşan BFA temelde karaciğer glukuronidasyon yolunda metabolize edilmektedir. BFA'nın biyolojik yarı ömrü yaklaşık 6 saattir ve 24 saatte idrarla neredeyse tamamı atılmaktadır. ${ }^{11}$ Hızlı metabolize edilmesine rağmen, BFA oldukça uzun bir süre dokularda birikebilir ve konjugasyondekonjugasyon döngüsüne dahil olabilir.12 BFA yetişkin serumunda $(0.2-20 \mathrm{ng} / \mathrm{mL})^{13}$, plesanta dokusunda $(1.0-104.9 \mathrm{ng} / \mathrm{g})^{14}$, anne sütünde (0.28-0.97 ng/mL), kolostrumda (1$7 \mathrm{ng} / \mathrm{mL})$ idrarda $(1,12 \mathrm{ng} / \mathrm{mL} \text { kadınlarda })^{15}$, farklı oranlarda bulunmuştur. Karaciğer detoksifikasyon enzimleri henüz tam olarak gelişmediği için özellikle fetal ve yenidoğan dönemde BFA'nın toksik etkilerine daha çok maruz kalındığı düşünülmektedir. ${ }^{16}$ Avrupa Gıda Güvenliği Otoritesi (EFSA) raporuna göre BFA'nın ratlarda gözlenebilen hiçbir yan etki göstermeyen dozu (NOEL) 5 $\mathrm{mg} / \mathrm{kg} /$ gün'dür ve kabul edilebilir günlük alım miktarı $0.05 \mathrm{mg} / \mathrm{kg} /$ gün'dür. ${ }^{17}$

BFA'nın endokrin bozucu özelliğini östrojen reseptörlerine bağlanarak gösterdiği östrojenik etki ile yaptığı laboratuvar çalışmalarında kanıtlanmıştır. BFA, nükleer östrojen reseptörlerine 17-beta östrodiol'e (E2) göre daha düşük afiniteyle bağlanmasına rağmen, nükleer olmayan östrojen reseptörlerine E2 ile benzer affiniteyle bağlanmaktadır.18 BFA, endojen E2 ile rekabet ederek östrojenik yanıtı bloke eden bir anti-östrojen gibi de davranabilir. ${ }^{19}$ Ayrıca BFA doğrudan androjen reseptörlerine bağlanarak endojen androjen aktivitesini engelleyip antiandrojenik etki de gösterebilir. ${ }^{7}$

Memeli ve memeli olmayan canlılarda yapılan birçok çalışma ile BFA'nın sağlık üzerine olumsuz etkileri kanıtlanmıştır. ${ }^{19-21}$ Literatür, BFA'ya çevresel maruziyetin insan sağlı̆̆ına zararlı olabileceği iddiasını desteklese de ${ }^{20}$, BFA'nın insanlar üzerine etkisini inceleyen çok az çalışma vardır. ${ }^{22} \mathrm{Bu}$ çalışma, insan temelli çalışmalarda BFA'nın üreme sağlığına olan etkisini inceleyip değerlendirmek amacıyla yapılmıştır.

\section{Gereç ve Yöntem}

Mart-Mayıs 2017 tarihleri arasında 'PubMed' veri tabanı kullanılarak tarama yapılmıştır. Manual arama ile eksik makaleler araştırılmıştır. Arama veri 
tabanına uygun arama metodu ve anahtar kelimelerle 'VE' ve 'VEYA' bağlacı kullanılarak yapılmıştır. $\mathrm{Bu}$ doğrultuda bisfenol A, BFA, endokrin bozucular, fertilite, üreme sağlığı, GnRH, puberte başlangıcl, uterus, endometriozis anahtar kelimeleri kullanılarak sadece İngilizce makaleler üzerinde araştırma yapılmıștır. Taramalar sonucunda ulaşılan 524 makaleden, İngilizce olmayan, tam metnine ulaşılamayanlar, derleme çalışmalar, meta-analizler, in vitro çalışmalar ve hayvan çalışmaları dışlanarak toplamda 23 makale çalışmaya dahil edilmiştir.

\section{Bulgular ve Tartışma}

\section{Fertilite}

İnfertilite yaklaşık 12 ay ve sonrası için zamanlanmış korunmasız cinsel ilişkiden sonra başarılı bir gebeliği yakalayamamak olarak tanımlanmaktadır. Çiftlerin \%10-15'inde görülen bir problemdir. ${ }^{23}$ Genelde, infertilite vakalarının yaklaşık \%35'i sadece kadınsal faktörlerden kaynaklanmaktadır. BFA çeşitli nedenlerle kadın $^{24}$ ve erkek ${ }^{25}$ fertilitesini geniş çapta etkilemektedir.

Yapılan bir çalışmada ${ }^{26} 70$ infertil erkek ve 83 fertil erkek dahil edilmiş ve büyükşehirde yaşayan infertil erkeklerde fertil erkeklere göre BFA seviyesi daha yüksek bulunmuştur. Özellikle büyükşehirde yaşayan bireylerde BFA'nın yüksek bulunması, bu bölgelerde kimyasalın ekonomik faaliyetlerinin fazla olduğu, gıda ticaretinde ve paketleme ürünlerinde kullanıldığını bu nedenle maruziyetin yüksek olduğunu yansıtmaktadır. Caserta ve $\operatorname{ark}^{27}$ yaşları 18-40 arasında değişen infertil kadın $(n=48)$ ve fertil kontrol grubu $(n=13)$ ile yaptıkları çalışmada kontrol grubuna göre infertil kadınların serum BFA düzeyinin anlamlı derecede daha yüksek olduğunu tespit etmişlerdir. Bu durum, BFA'nın infertiliteye etki edebileceğini göstermektedir.

Souter ve $\operatorname{ark}^{28}$ yaptığ prospektif kohort bir çalışmaya infertilite tedavisi altındaki 209 kadın dahil edilmiştir. Kadınların \%80'inden fazlasında özgül ağırlığa göre düzenlenmiş idrar BFA düzeyi saptanmıștır. Kadınlarda idrar BFA düzeyi folikül uyarıcı hormon (FSH) düzeyi ve yumurtalık hacmi ile ilişkili bulunmazken, yüksek idrar BFA düzeyi daha düşük antral folikül sayısı ile ilişkili bulunmuştur. Yapılan bir başka çalışmada ${ }^{29}$ in vitro fertilizasyon (IVF) tedavisi alan 18-45 yaş arası kadınları incelemişlerdir. IVF tedavisi alan kadınların implamantasyon başarısı aşılamadan 15-20 gün sonra beta-hCG düzeyi ile ölçülmüştür. Yüksek idrar BFA konsantrasyonuna sahip olan kadınlarda yüksek implantasyon başarısızlığı (düzenlenmemiş değerlerde) ve en yüksek BFA düzeyine sahip olanlarda bu başarısızlığın iki kat daha fazla olduğu gözlenmiștir. Değerler düzenlendiğinde bu farklılık devam etse de sonuçlar istatistiksel olarak anlamlı bulunmamıştır ( $\mathrm{p}=0.06)$.

\section{California Üniversitesi San Francisco} (UCSF) Üreme Sağlığı Merkezi'inde IVF tedavisi altındaki çiftlerin dahil edildiği bir çalışmada $^{30}$ kadınlarda yüksek konjuge olmayan serum BFA düzeyi düşük serum E2 düzeyi ile ilişkili bulunmuştur. Foliküler stimülasyonun kesin bir ölçümü olan olgun folikül başına düşen E2 düzeyi ile yüksek konjuge olmayan serum BFA düzeyi arasında güçlü bir iliş̧i olduğu tespit edilmiştir. MokLin ve $\operatorname{ark}^{31}$ da IVF tedavisi altındaki 84 kadın ile yaptıkları çalışmada özgül ağırlığa göre düzenlenmiş idrar BFA düzeyi ile pik E2 seviyesi arasında ters ilişki belirlemiştir. Ancak her iki çalışmada oosit sayısı ve BFA düzeyi arasında farklı sonuçlar bulunmuştur. Mok-Lin ve $\operatorname{ark}^{31}$ BFA ve siklus başına düşen oosit sayısı arasında bir ilişki olduğunu belirtirken, Bloom ve $\operatorname{ark}^{30}$ bir ilişki olmadı̆̆ını göstermiştir. Bunun nedeninin toplam BFA yerine konjuge olmayan BFA ölçümünün kullanılmasından kaynaklanabileceği düşünülmektedir.

Minguez-Alarcon ve $\operatorname{ark}^{32}$ IVF tedavisinin orta ve son aşamasındaki yaşları 18-45 yıl arasında değișen 256 kadının idrar BFA düzeyi ile klinik gebelik veya canlı doğum sayıları arasındaki ilişkiyi incelemişlerdir. İdrar BFA konsantrasyonu ile implantasyon, klinik gebelik veya canlı doğum oranları arasında siklüs veya embriyo transferi başına bir ilişki bulunmamıştır. Daha genç olan kadınlarda ( $<37$ yaşında) idrar BFA konsantrasyonları endometrium kalınlığı ile ilişkili bulunurken, daha yaşlı 
kadınlarda ( $\geq 37$ yaş) tam tersi bir sonuç bulunmuştur. Yaşın bu süreci nasıl etkilediği tam olarak açılklanamamıștır. ${ }^{32}$ Louis ve ark $^{33}$ da yaptıkları prospektif kohort çalışmada korunmayı bırakıp çocuk sahibi olmak isteyen çiftleri değerlendirdiklerinde, doğurganlık ve hamile kalma zamanı ile BFA düzeyi arasında ilişki belirlememişlerdir. $\mathrm{Bu}$ çalışmaların aksine, yapılan bir başka çalışmada ${ }^{34}$ IVF tedavisi alan kadınlarda BFA düzeyi ile implantasyon başarısızlı̆gı arasında pozitif bir ilișki bulunmuștur.

Tüm bu çalıșmalar uygun bir șekilde tasarlanmıș ve iyi yürütülmüștür. Ancak çoğunda örneklem sayısının düşük olduğu (Tablo 1) görülmektedir. Araştırmacılar da sonuçların doğrulanması için daha fazla çalışmaya ihtiyaç duyulduğuna işaret etmektedir. Bazı sonuçlar istatistiksel olarak anlamlı bulunsa da, etkileri çok geniş çaplı olarak değerlendirilememiştir. Bununla birlikte, yapılan benzer çalışmalar farklı popülasyonlarda tekrarlandığında ortaya çıkan sonuçlar birbiri ile tutarlıdır. Çalışmalar infertil çiftler veya IVF tedavisi altındaki bireyler üzerinde yürütüldüğünden, bu çalışmaların sonuçlarını genel popülasyona uyarlamak doğru olmayabilir. Çalışmalara dahil edilen bireylerin 1/3'ü 'kadınsal faktörlerden', $1 / 3$ 'ü 'erkeksel faktörlerden' ve diğer $1 / 3$ 'ü açıllanamayan nedenlerden dolayı infertilite tanısı konduğu için ne kadın ne de erkek infertilitesinin BFA'ya daha duyarlı olduğunu tek başına açıklamak için yeterli değildir. ${ }^{27,29,30,32}$

\section{Erkek Cinsel Fonksiyonu}

Bu konu ile ilgili yapılan iki tane geniş çaplı araştırma bulunmaktadır. Bunlardan biri Li ve ark $^{35}$ tarafindan BFA'ya mesleki anlamda maruz kalan 427 erkek işçinin cinsel performanslarının incelendiğ $i$ çalışmadır. Katılımcıların kreatine göre düzenlenmiş idrar BFA düzeyi 1.2-53.7 $\mu \mathrm{g} / \mathrm{g}$ olarak tespit edilmiştir. İdrar BFA düzeyinin artması, cinsel istekte azalma $(\mathrm{p}<0.001)$, ereksiyon zorluğunda artış $(p<0.001)$, boşalma kuvvetinde $(p<0.001)$ ve cinsel tatminde azalma $(\mathrm{p}<0.01)$ ile ilişkili bulunmuştur. $\mathrm{Bu}$ bulgu, yüksek dozlarda BFA'ya maruziyetin önemli halk sağlığ sorunlarına neden olabileceğine işaret etmektedir. Bir diğeri de Liu ve arkadaşlarının $^{36}$ BFA'ya maruz kalan ve kalmayan erkekler üzerinde yaptıkları idrar BFA düzeyinin serum reprodüktif hormonların düzeyleriyle ilişkili olup olmadığını araştıran çalışmadır. İdrar BFA düzeyinin artması, yükselmiş prolaktin $(p<0.001)$, östradiol $(p<0.001)$, cinsiyet hormon bağlayıcı globülin (SHBG) düzeyi $(\mathrm{p}=0.001)$ ve azalmış androstenedion $(p<0.001)$ ve serbest androjen indeksi düzeyi $(p=0.021)$ ile ilişsili bulunmuştur. Yüksek BFA maruziyeti artmış prolaktin, ösrodiol ve SHBG seviyesi ile ilişkili bulunmasının erkek infertilitesine neden olabileceğini düşündürmektedir.

toksik Her iki çalışmada da, diğer çevresel değerlendirilmiștir. Önceki mesleki kimyasal veya ağır metallere olan maruziyetin bu sonuçlar üzerine etkisinin olmadığı belirtilmektedir. ${ }^{35,36}$ Yapılan çalışmalarda geriye dönük BFA maruziyetinin iyi bir şekilde sorgulanması, örneklem sayılarının fazla olması çalışmanın güçlü yönlerini göstermektedir. Maruziyetlerin iyi değerlendirilip sınıflandırılması açısından mesleki maruziyet çalışmaları diğerlerine kıyasla daha güçlü çalışmalardır. BFA maruziyeti ve erkek cinsel fonksiyonu arasındaki ilişki başka kohort çalışmalar ile desteklenebilir.

\section{Sperm Kalitesinde Azalma}

Memelilerde spermatogenez süreci, hipotalamus-hipofiz-testiküler aksı ve tiroid bezleri tarafından koordine edilmektedir. ${ }^{37}$ BFA gibi endokrin bozucuların tetiklediği akstaki fonksiyon bozuklukları spermatogenezin değişmesi veya durması ile sonuçlanabilir. ${ }^{1}$ Çevresel toksinlerin erkek üreme fonksiyonları üzerinde gösterdikleri olumsuz bir başka önemli mekanizma da testislerin pro-oksidan-antioksidan dengesini değiştirerek testiküler fonksiyonların bozulmasıdır. ${ }^{38}$ BFA gibi çevresel toksinlere maruz kalma reaktif oksijen türevleri (ROS) üretimini arttırmaktadır ve testiküler oksidadif strese yol açmaktadır. BFA hem epididimis hem de sperm hücrelerinde antioksidan enzim 
aktivitelerini azaltmakta ve lipit peroksidasyonuna neden olmaktadır. $\mathrm{Bu}$ yüzden, üreme organlarında ROS'u azaltmak BFA'nın yol açtığı sorunları hafifletmek için iyi bir yaklaşım olabilir. Yapılan bir çalışmada ${ }^{25}$ infertilite kliniğinde tedavi gören yaşları 18-55 yıl arasında değişen 190 erkekte istatistiksel olarak anlamlı olmasa da BFA maruziyeti (idrar BFA konsantrasyonu) ile değişmiş sperm parametreleri (azalmış sprem sayısı, değişmiş morfoloji ve hareketlilik, artmış sperm DNA hasarı) arasında pozitif bir ilişki bulunmuștur.

Goldstone ve $\operatorname{ark}^{39}$ 'nın sağlıklı, evli veya ilişkisi olan 18 yaş üstü erkeklerden oluşan 418 kişiyi değerlendirdikleri bir çalışmada idrar BFA düzeyi ile semen kalitesi arasında bir ilişki bulunmamıştır. Knez ve ark ${ }^{40}$ 'nın ilk veya ikinci IVF veya intrasitoplazmik sperm enjeksiyonu (ICSI) prosedürü uygulanan 149 çifti değerlendirdikleri çalışmada katılımcıların \%98'inde BFA tespit edilmiştir. Subfertil erkeklerin idrar BFA düzeylerinin semen kalitesini etkileyebileceği ancak, blastosist aşamasına kadar embriyo gelişimini etkilemediği sonucuna varılmıştır.

Yapılan

değerlendirildiğinde insanlar üz̧erinde yapılan epidemiyolojik araştırma kapsamına alınan grupların özelliklerinin farklı olması, katılımcı sayısının yetersiz olması gibi nedenlerden dolayı idrar BFA seviyesi ile sperm kalitesi arasında ilişki tam olarak açıklanamamıştır. ${ }^{25,40}$

\section{Cinsiyet Hormon Konsantrasyonları}

Prenatal ve postnatal gelişimin önemli dönemlerinde cinsiyete özgü fizyolojik süreçlerin koordine edilmesinde nöroendokrin döngünün düzgün çalışması hayati önem taşımaktadır. BFA maruziyetinin cinsel farklılaşma, gonatropin-salıcl hormon (GnRH), hipotalamik ER ve lüteinleștirici hormonun (LH) salınımındaki değişikliklere neden olduğu düşünülmektedir. ${ }^{41} \mathrm{Bu}$ konu ile ilgili yapılan çalışmalar erkek cinsiyet hormonları üzerine olduğu için, öncelikle sağlıklı sperm üretimindeki fizyolojik mekanizmaların bilinmesi gerekmektedir. Erkek üreme sisteminin gelişiminde spesifik yolakların androjen ve anti-Müllerian hormonlar tarafından aktive edilmesi gerekmektedir. Testis oluşumunun kendisi hormona duyarlı olmasa da maskülinizasyonun diğer birçok yönü normal testiküler hormon üretimine bağlıdır. Ayrıca, testis hücre gelişimi (testis oluşumunun tersine) hormonların lokal etkilerinden etkilenmektedir. ${ }^{42}$ Androjenler, epididime, vaz deferens ve seminal veziküllere ayrılan Wolff kanallarının normal gelişiminde en etkili olan önemli hormonlardır. ${ }^{43} \mathrm{Bu}$ nedenle erkek genitoüriner sistemin normal gelişim gösterebilmesi için dengeli bir hormonal çevreye ihtiyaç vardır. Hormonal sorunlar maskülinizasyon anomalileri ile ilişkilidir. Meeker ve $\operatorname{ark}^{44}$ bir klinikte tedavi görmek isteyen subfertil çiftlerin erkeklerini $(\mathrm{n}=167)$ değerlendirdikleri kesitsel bir çalışmada yüksek idrar BFA düzeyi ile daha yüksek FSH ve daha düşük inhibin $B$ düzeyi arasında ilişki olduğunu tespit etmişlerdir. Ayrıca, yüksek BFA düzeyi daha düşük TSH konsantrasyonu ile de ilişkili bulunmuştur. $\mathrm{Bu}$ çalışmanın sonuçları idrar BFA konsantrasyonu ile erkeklerde hormon düzeylerin değișebileceğini desteklemektedir. ${ }^{44}$ Yapılan bașka bir çalışmada ${ }^{45}$ da yüksek idrar BFA düzeyinin düşük serbest androjen indeksi (FAI), serbest testesteron (FT) konsantrasyonu ve yüksek SHBG düzeyi ile ilişkili olduğu bulunmuştur.

$\mathrm{Bu}$ konu ile ilgili ulaşılabilen çalışma sayısı az olmasına rağmen iki çalışmanın sonuçlarının tutarlı ve istatistiksel analiz sonuçlarının anlamlılık düzeylerinin $(\mathrm{p}<0.001)$ olması BFA'nın dolaşımdaki cinsiyet hormon konsantrasyonlarını değiştirebileceğini göstermektedir.

\section{Polikistik Over Sendromu (PCOS)}

Polikistik over sendromu (PCOS) üreme dönemindeki kadınlar arasında sıklıkla karşılașılan ve hiperandrojenizm, insülin direnci ve kronik anovülasyon ile karakterize bir endokrinopatidir. PCOS patogenezinde bir endokrin bozucu olan BFA'nın etkinliği son zamanlarda daha sık gündeme gelmiştir. ${ }^{46}$ PCOS olan ve olmayan kadınlar ile yapılan bir çalışmada, kontrol 
grubu ile karşılaştırıldığında PCOS olan kadınların toplam serum BFA düzeyi anlamlı derecede daha yüksek bulunmuştur. Bunun yanı sıra, BFA ve yüksek androjen konsantrasyonları arasında da anlamlı bir ilişki bulunmuştur. ${ }^{47}$ Androjen seviyesinin artışı farklı mekanizmalar ile açıklanabilir. Yapılan rat çalışmalarında GnRH/LH atım frekansinın $\operatorname{artmasi}^{48}$ ve BFA'nın karaciğerdeki androjen metabolizmasını değiştirerek SHBG'nın güçlü bir ligandı gibi aktivite göstermesi böylece androjenlerin yerini alarak serbest androjen miktarını arttırması mekanizmalar içerisinde sayılabilir. ${ }^{47}$ Takeuchi ve $\operatorname{ark}^{49}$ obez ve obez olmayan PCOS'lu kadınlarda serum BFA konsantrasyonunu anlamlı ölçüde daha yüksek bulmuşlardır. Sağlıklı obez kadınlar ile obez ve PCOS'lu kadınlar karşılaştırıldığında da aynı sonuca ulaşılmıştır. Aynı çalışmada, yüksek serum BFA düzeyinin toplam ve serbest testosteron, androstenedion ve dehidroepiandrosteron sülfat (DHEAS) düzeyleri ile anlamlı derecede ilișkili olduğu tespit edilmiştir. $\mathrm{Bu}$ sonuçlar BFA'nın yetişkin kadınlarda androjen konsantrasyonunu arttırabileceğini düşündürmektedir. ${ }^{49}$ PCOS ve BFA arasındaki ilişkinin altında yatan nedenin BFA'ya bağlı insülin direncindeki artış ve serbest androjenin yanı sıra kronik, düşük dereceli inflamasyonu içeren çift yönlü mekanizma olduğu hipotezi de bulunmaktadır. 46

\section{Endometriyal Rahatsizlıklar}

Endometriozis, uterus boşluğunun dişında büyüyen endometriyal bezler ve stroma ile karakterize jinekolojik bir hastalıktır. ${ }^{50}$ BFA'nın ERs ile etkileşim kurabilme yeteneği, BFA östrojen-bağımlı patolojinin gelişimine neden olabilir. Rahim içinde güçlü östrojenik aktivite gösteren bir ilaç olan dietilstilbestrola (DES) maruz kalınmasına bağlı olarak endometriozisin geliştiğine dair güçlü epidemiyolojik veriler bulunmaktadır.50 Fakat BFA maruziyeti hakkında çok az şey bilinmektedir. Bir pilot çalışmada, Cobellis ve ark $^{51} \mathrm{BFA}$ ve daha az araştırılsa da bisfenol B (BFB) ile endometriozis varlığı arasındaki ilişkiyi incelemişlerdir. Sağlıklı kadınların serumlarinda BFA veya BFB'ye rastlanmamıştır. Bunun aksine, araştırmacılar endometriozisli 58 hastanın serumlarının \%63.8'inde bisfenollerden en az birine; \%51.7'sinde BFA ve \%27.6'sinda BFB saptanırken, \%15.5'inde her ikisi de bulunmuştur. ${ }^{51}$ Yaşları 18-49 yl arasında değișen endometriozis tanısı alan ve sağlıklı kontrol grubu olmak üzere toplamda 430 kadın üzerinde yapılan başka bir çalışmada, idrar BFA konsantrasyonu ile endometrioz arasında ilişki bulunmazken, ovaryan olmayan pelvik endometriozisle pozitif ilişki bulunmuştur. ${ }^{52}$ Hiroi ve ark ${ }^{53}$ 'nı 37 kişi ile yaptıkları vaka-kontrol çalışmasında BFA maruziyeti ile endometriyal kanser ve kompleks endometriyal hiperplazi arasında ilişki bulunmuştur. Farklı biyobelirteçlere maruz kalmanın farklı anlamlara gelebileceği göz ardı edilmemelidir. İdrar BFA konsantrasyonu ${ }^{52}$ tüm çevresel maruziyeti yansitırken, serum BFA düzeyi sadece hedef doku maruziyetinin bir göstergesi olabilir. ${ }^{51}$

BFA ve endometriozis arasındaki çelişkili sonuçlar değerlendirildiğinde prospektif, kontrollü ve iyi tasarlanmış çalışmalara daha fazla ihtiyaç olduğu söylenebilir.

\section{Sonuç ve Öneriler}

Son dönem yapılan insan çalışmaları yetişkinlik döneminde BFA maruziyetinin ovaryan cevapta IVF ve fertilizasyon başarısında azalma ve embriyo kalitesi, erkek cinsel işlev bozukluğu, sperm kalitesinde düşme, cinsiyet hormon konsantrasyonlarında değişme ve PCOS ile ilişkili olduğunu göstermektedir. İn vitro çalışmalar ve in vivo hayvan çalışmaları, çevresel açıdan önemli dozlarda BFA maruziyetlerinin üreme sağlığı üzerine olumsuz etkisinin bulunduğunu göstermektedir. $., 30,38,39$

Dünyada yılda 3.5 milyon tondan fazla BFA üretilip, birçok ürünün içerisinde kullanılmaktadır. ${ }^{54}$ Yukarıda belirtilen çok sayıda bulgu göz önüne alındığında, yaptığı meslekten dolayı BFA'ya maruz kalmak zorunda olan bireylere ve ailelerine oluşabilecek riskler hakkında eğitimler 
verilip bireyler bilgilendirilmelidir. Mesleki açıdan maruz kalan bireylerin değerlendirildiği çalışmaların sonuçları genel popülasyona göre daha güçlü ilişkilerin var olduğunu göstermektedir. Ancak, mesleki açıdan maruz kalmayan popülasyonda yapılan çalışmaların çoğunda (Tablo 1), düşük doz BFA'ya maruz kalınmasının bile sağlık üzerinde önemli olumsuz etkilerinin olduğu ortaya konmaktadır.

Yapılan çalışmaların bir kısmı sadece infertilite tedavisi altındaki bireyleri değerlendirmiștir (Tablo 1). Bu çalıșmaların sonuçlarında açı̆̆a çıkan olumsuz etkiler genel popülasyona uyarlanamasa da, BFA'nın infertiliteye neden olabileceğini veya infertil bireylerin BFA'nın etkilerine karşı daha duyarlı olabileceğini göstermektedir. Batı toplumlarında infertilite oranı giderek artış gösterdiği için ${ }^{55}$, BFA'nın olumsuz etkilerini oraya koymak daha büyük önem tașımaktadır. BFA'nın infertilite üzerine etkisini genel popülasyona uyarlayabilmek için daha fazla çalışmaya ihtiyaç duyulmaktadır.

İncelenen bu çalışmalar ışığında, gelişimsel ve yetişkin dönemdeki maruziyetler arasındaki farklılığın anlaşılması önemlidir. BFA insan vücudunda yaklaşık 6 saat içerisinde metabolize olup

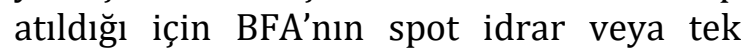
seferde alınan serum örneklerindeki düzeyi uzun dönem BFA maruziyetini yansıtmayabilir ${ }^{11}$. $\mathrm{Bu}$ örneklerde yapılan analizler hormon konsantrasyonları ve gen ekspresyonu gibi aktif değişiklikleri doğru bir şekilde öngörebilir.44,45,49 Fakat spot numunelerin yetişkinlerde uzun vadeli BFA maruziyetini yansıttığını destekleyen çalışmalar da bulunmaktadır. ${ }^{56}$ Çalışmaların sonuçları göz önüne alındığında, BFA maruziyetinin azaltılması hastalıkların önlenmesinde koruyucu bir faktör olabilir.

Bisfenol A'ya birincil maruz kalma yolu besinlerin tüketilmesi ile olmaktadır. $\mathrm{Bu}$ nedenle, tüketilen hazır ambalajlı ürünlerin ve kullanılan plastiklerin günlük kullanımı azaltılmalıdır. Plastik kaplar yerine cam veya seramik ürünler tercih edilmelidir. ${ }^{57}$ Mikrodalgaya özgü ağzı kapalı kaplar kullanılarak BFA'ya daha az maruz kalınabilir.

BFA güvenilir doz düzeyi $50 \mu \mathrm{g} / \mathrm{kg} /$ gün olarak belirtilse de yapılan çalışmalarda daha düşük dozların bile sağlık üzerine olumsuz etkilerinin olduğu belirtilmektedir. ${ }^{58} \mathrm{Bu}$ nedenle güvenilir doz düzeyinin daha alt sınırlara çekilmesi önerilmektedir. Günümüzdeki güncel literatür, çevresel BFA maruziyetinin insanlar için bir sağlı riski oluşturabileceğini göstermektedir ve insan sağlığını korumak için ürünlerdeki BFA içerikleri tekrardan gözden geçirilmelidir. 
Tablo 1: Bisfenol A ile ilgili yapılan çalışmalar

\begin{tabular}{|c|c|c|c|c|c|c|}
\hline Çalıșmacılar & Kategori & Çalışma deseni & Sayı & Çalışılan grup & BFA düzeyi & Sonuç \\
\hline $\begin{array}{l}\text { Meeker ve ark } \\
25\end{array}$ & $\begin{array}{l}\text { Semen } \\
\text { kalitesi/sperm } \\
\text { DNA hasarı }\end{array}$ & $\begin{array}{l}\text { Prospektif } \\
\text { kohort }\end{array}$ & 190 & $\begin{array}{l}\text { Subfertil tedavi gören } \\
18-55 \text { yaș erkekler }\end{array}$ & $1,3 \mathrm{ng} / \mathrm{mL}(\% 89)^{\mathrm{c}}$ & $\begin{array}{l}\text { İdrar BFA düzeyi azalmış semen kalitesi ve } \\
\text { artmış sperm hasarı ile ilişkilidir. }\end{array}$ \\
\hline $\begin{array}{l}\text { Souter ve ark } \\
28\end{array}$ & Fertilite & $\begin{array}{l}\text { Prospektif } \\
\text { kohort }\end{array}$ & 209 & $\begin{array}{l}\text { İnfertilite tedavisi } \\
\text { gören 21,6-46,7 yaş } \\
\text { kadınlar }\end{array}$ & 1,$6 ; 1,7 ; 1,5 \mu \mathrm{g} / \mathrm{L}^{\mathrm{a}}$ & $\begin{array}{l}\text { İdrar BFA düzeyi, FSH veya OV ile ilişkili } \\
\text { değilken; yüksek idrar BFA daha düşük AFC } \\
\text { ile ilişkilidir. }\end{array}$ \\
\hline $\begin{array}{l}\text { Goldstone ve } \\
\operatorname{ark}^{39}\end{array}$ & Semen kalitesi & $\begin{array}{l}\text { Prospektif } \\
\text { kohort }\end{array}$ & 418 & $\begin{array}{l}\text { Sağlıkl, evli veya } \\
\text { ilişkisi olan } 18 \text { yaş } \\
\text { üstü erkekler }\end{array}$ & $0,55 \mathrm{ng} / \mathrm{mL}^{\mathrm{a}}$ & $\begin{array}{l}\text { İdrar BFA düzeyi ile semen kalitesi arasında } \\
\text { ters ilişki bulunmamıştır. }\end{array}$ \\
\hline Lİ ve ark 35 & $\begin{array}{l}\text { Erkek cinsel } \\
\text { fonksiyonu }\end{array}$ & $\begin{array}{l}\text { Kohort } \\
\text { (mesleki } \\
\text { maruziyeti } \\
\text { olanlar) }\end{array}$ & 427 & $\begin{array}{lr}\text { BFA veya } & \text { epoksi } \\
\text { reçine } & \text { üreten } \\
\text { fabrikalarda } & \text { çalışan } \\
\text { erkek ve } & \text { maruz } \\
\text { kalmayan } & \text { kontrol } \\
\text { grubu } & \end{array}$ & $1,2-53,7 \mu \mathrm{g} / \mathrm{g} b, \mathrm{c}$ & $\begin{array}{l}\text { Yüksek idrar BFA düzeyi ile bireylerin beyan } \\
\text { ettiği cinsel işlevlerinin düşüklüğü arasında } \\
\text { korelasyon bulunmuştur. }\end{array}$ \\
\hline Knez ve ark ${ }^{40}$ & $\begin{array}{l}\text { Semen } \\
\text { kalitesi/embriyo } \\
\text { gelişimi }\end{array}$ & $\begin{array}{l}\text { Prospektif } \\
\text { kohort }\end{array}$ & 149 & $\begin{array}{lr}\text { IVFR } & \text { veya ICSI } \\
\text { tedavisi } & \text { altındaki } \\
\text { çiftler } & \end{array}$ & $1,55 \mathrm{ng} / \mathrm{mL}^{\mathrm{a}}$ & $\begin{array}{l}\text { Subfertil erkeklerin idrar BFA düzeyi semen } \\
\text { kalitesini etkileyebilir ancak, blastosit } \\
\text { aşamasına kadar embriyo gelişimini } \\
\text { etkilemez. }\end{array}$ \\
\hline $\begin{array}{l}\text { Upson ve ark } \\
52\end{array}$ & $\begin{array}{l}\text { Endometriyal } \\
\text { hastalıklar }\end{array}$ & Vaka-kontrol & 430 & $\begin{array}{l}\text { Endometriosiz } r \text { ve } \\
\text { sağlıklı kontrol } 18-49 \\
\text { yaş }\end{array}$ & $1,24-1,32 \mu \mathrm{g} / \mathrm{g}^{\mathrm{b}}$ & $\begin{array}{l}\text { İdrar BFA ile endometriozis arasında ilișki } \\
\text { bulunmamış, ancak ovaryan olmayan pelvik } \\
\text { endometriozisle pozitif iliş̧ki bulunmuştur. }\end{array}$ \\
\hline $\begin{array}{l}\text { Bloom ve ark } \\
30\end{array}$ & Fertilite & $\begin{array}{l}\text { Prospektif } \\
\text { kohort }\end{array}$ & 44 & $\begin{array}{l}\text { IVF tedavisi altındaki } \\
31-19 \text { yaş arası } \\
\text { kadınlar }\end{array}$ & $2,5 \mathrm{ng} / \mathrm{mL}^{\mathrm{d}}$ & $\begin{array}{l}\text { Daha yüksek BFA hCG ile hiperstimülasyona } \\
\text { cevap olarak daha düşük pik E2 ile ilişkili } \\
\text { bulunmuştur. }\end{array}$ \\
\hline Liu ve $\operatorname{ark}^{36}$ & $\begin{array}{l}\text { Cinsiyet hormon } \\
\text { konsantrasyonu }\end{array}$ & $\begin{array}{l}\text { Kesitsel } \\
\text { çalışma }\end{array}$ & 592 & $\begin{array}{lr}\text { BFA veya } & \text { epoksi } \\
\text { reçine } & \text { üreten } \\
\text { fabrikalarda çalışan- } \\
\text { maruz } \\
\text { erkek }\end{array}$ & $\begin{array}{l}685,9-4,2 \mu \mathrm{g} / \mathrm{gCr}^{\mathrm{b}} \\
\text { (medyan) }\end{array}$ & $\begin{array}{l}\text { Yüksek BPA'ya maruz kalma erkeklerde } \\
\text { artmış prolaktin, E2 ve seks hormon } \\
\text { bağlayıcı globulin düzeyleri (SHBG) ile } \\
\text { ilişkilidir. }\end{array}$ \\
\hline
\end{tabular}




\section{Tablo 1'in devamı}

\begin{tabular}{|c|c|c|c|c|c|c|}
\hline Çalışmacılar & Kategori & $\begin{array}{l}\text { Çalışma } \\
\text { deseni }\end{array}$ & Sayı & Çalışılan grup & BFA düzeyi & Sonuç \\
\hline $\begin{array}{l}\text { Minguez- } \\
\text { Alarcon ve } \\
\text { ark }^{32}\end{array}$ & Fertilite & $\begin{array}{l}\text { Prospektif } \\
\text { kohort }\end{array}$ & 256 & $\begin{array}{l}\text { IVF tedavisinin orta veya } \\
\text { son aşamasındaki 18-45 } \\
\text { yaş kadın }\end{array}$ & $1,87 \mu \mathrm{g} / \mathrm{L}^{\mathrm{a}, \mathrm{e}}$ & $\begin{array}{l}\text { Üriner BFA konsantrasyonları } \\
\text { implantasyon, klinik gebelik veya canlı } \\
\text { doğum oranları arasında siklüs başına veya } \\
\text { embriyo transferi başına ilişki } \\
\text { bulunmamıştır. }\end{array}$ \\
\hline $\begin{array}{l}\text { Ehrlich ve ark } \\
29\end{array}$ & Fertilite & $\begin{array}{l}\text { Prospektif } \\
\text { kohort }\end{array}$ & 174 & $\begin{array}{l}\text { IVF tedavisi alan } 18-45 \\
\text { yaş kadınlar }\end{array}$ & $2,3 \mu \mathrm{g} / \mathrm{L}^{\mathrm{e}}$ & $\begin{array}{l}\text { Yüksek BFA kötü yumurtalık cevabı, olgun } \\
\text { oosit sayısında azalma ve normal fertilize } \\
\text { oositlerin sayısının azalması ile ilişkili } \\
\text { bulunmuştur. }\end{array}$ \\
\hline $\begin{array}{l}\text { Meeker ve ark } \\
44\end{array}$ & $\begin{array}{l}\text { Cinsiyet hormon } \\
\text { konsantrasyonu } \\
\text { /tiroid } \\
\text { fonksiyonu }\end{array}$ & $\begin{array}{l}\text { Kesitsel } \\
\text { çalışma }\end{array}$ & 167 & $\begin{array}{l}\text { Bir klinikte tedavi } \\
\text { görmek isteyen subfertil } \\
\text { çiftlerin erkekleri }\end{array}$ & $1,3 \mu \mathrm{g} / \mathrm{Le}^{\mathrm{e}}$ & $\begin{array}{l}\text { Yüksek idrar BFA yüksek FSH düşük inhibin } \\
\text { B ve düșük TSH konsantrasyonu ile de } \\
\text { ilişkilidir. }\end{array}$ \\
\hline $\begin{array}{l}\text { Cobellis ve } \\
\operatorname{ark}^{51}\end{array}$ & $\begin{array}{l}\text { Endometriyal } \\
\text { rahatsızlıklar }\end{array}$ & Vaka-kontrol & 69 & $\begin{array}{l}\text { Endometriyozisli ve } \\
\text { sağlıklı 18-44 yaş arası } \\
\text { kadınlar }\end{array}$ & $2,9 \mu \mathrm{g} / \mathrm{L}^{\mathrm{d}}$ & $\begin{array}{l}\text { Kontrol grubu } \text { ile karşılaştırıldığında } \\
\text { endometriyozisli kadınların serum BFA } \\
\text { düzeyi belirgin derecede daha yüksek } \\
\text { bulunmuştur }\end{array}$ \\
\hline $\begin{array}{l}\text { Mendiola ve } \\
\operatorname{ark}^{45}\end{array}$ & $\begin{array}{l}\text { Cinsiyet hormon } \\
\text { konsantrasyonu } \\
\text { /sperm kalitesi }\end{array}$ & $\begin{array}{l}\text { Kesitsel } \\
\text { çalışma }\end{array}$ & 375 & Fertil erkekler & $1,5 \mu \mathrm{g} / \mathrm{L}^{\mathrm{f}}$ & $\begin{array}{l}\text { Artmış idrar BFA azalmış FAI, FT, seminal } \\
\text { hacim ve yüksek SHBG ile anlamlı olarak } \\
\text { ilişkili bulunmuştur. }\end{array}$ \\
\hline $\begin{array}{l}\text { Caserta ve ark } \\
27\end{array}$ & Fertilite & Vaka-kontrol & 61 & $\begin{array}{l}\text { Yaşları } 18-40 \text { arasındaki } \\
\text { infertil kadın ve fertil } \\
\text { kontrol }\end{array}$ & Belirtilmemiş & $\begin{array}{l}\text { Kontrol grubuna göre infertil kadınların } \\
\text { serum BFA düzeyi anlamlı derecede daha } \\
\text { yüksek bulunmuştur. }\end{array}$ \\
\hline $\begin{array}{l}\text { Takeuchi ve } \\
\text { Tsutsumi } 49\end{array}$ & $\begin{array}{l}\text { Cinsiyet hormon } \\
\text { konsantrasyonla } \\
\text { rl/PCOS }\end{array}$ & Vaka-kontrol & 41 & $\begin{array}{l}\text { Sağlıklı kadın ve PCOS’lu } \\
\text { kadınlar }\end{array}$ & $0,6-1,5 \mu \mathrm{g} / \mathrm{L}^{\mathrm{d}}$ & $\begin{array}{l}\text { Kontrol grubuna göre PCOS'lu kadınların } \\
\text { serum BFA düzeyi daha yüksek bulunmuştur. }\end{array}$ \\
\hline $\begin{array}{l}\text { Kandaraki ve } \\
\operatorname{ark} 47\end{array}$ & $\begin{array}{l}\text { Cinsiyet hormon } \\
\text { konsantrasyonla } \\
\text { rl/PCOS/diyabet }\end{array}$ & Kesitsel & 171 & $\begin{array}{l}\text { PCOS’lu olan ve olmayan } \\
\text { kadınlar (zayıf ve obez } \\
\text { alt gruplarına ayrılmış) }\end{array}$ & $0,7-1,1 \mu \mathrm{g} / \mathrm{L}^{\mathrm{d}}$ & $\begin{array}{l}\text { Serum BFA PCOS'lu ve obez olan kadınlarda } \\
\text { anlamlı derecede daha yüksek bulunmuștur } \\
\text { (kontrol ve PCOS alt gruplarına göre) }\end{array}$ \\
\hline
\end{tabular}


Tablo 1'in devamı

\begin{tabular}{|c|c|c|c|c|c|c|}
\hline Çalışmacılar & Kategori & Çalışma deseni & Sayı & Çalışılan grup & BFA düzeyi & Sonuç \\
\hline Li ve $\operatorname{ark}^{59}$ & $\begin{array}{l}\text { Erkek cinsel } \\
\text { fonksiyonu }\end{array}$ & $\begin{array}{l}\text { Kohort } \\
\text { (mesleki } \\
\text { maruziyeti } \\
\text { olanlar) }\end{array}$ & 550 & $\begin{array}{lr}\text { BFA veya } & \text { epoksi } \\
\text { reçine } & \text { üreten } \\
\text { fabrikalarda } & \text { çalışan } \\
\text { erkek ve } & \text { maruz } \\
\text { kalmayan } & \text { kontrol } \\
\text { grubu } & \\
\end{array}$ & $1,2-57,9 \mu \mathrm{g} / \mathrm{g}^{\mathrm{b}}$ & $\begin{array}{l}\text { Doza bağımlı olarak, mesleki maruziyeti olan } \\
\text { işçiler kontrol grubuna göre beyan ettikleri } \\
\text { cinsel fonksiyonları anlamlı derecede daha } \\
\text { az bulunmuştur. }\end{array}$ \\
\hline $\begin{array}{l}\text { Mok-Lin ve } \\
\operatorname{ark}^{31}\end{array}$ & Fertilite & $\begin{array}{l}\text { Propektif } \\
\text { kohort }\end{array}$ & 84 & $\begin{array}{l}\text { IVF tedavisi alan } 21- \\
44 \text { yaş kadınlar }\end{array}$ & $<0.4-25.5 \mu \mathrm{g} / \mathrm{L}^{\mathrm{e}}$ & $\begin{array}{l}\text { BFA, oosit sayısı ve pik estradiol seviyesi ile } \\
\text { ters ilişkili bulunmuştur. }\end{array}$ \\
\hline Louis ve $\operatorname{ark}^{33}$ & Fertilite & $\begin{array}{l}\text { Propektif } \\
\text { kohort }\end{array}$ & 210 & $\begin{array}{lr}\text { Korunmayı } & \text { bırakıp } \\
\text { çocuk sahibi } & \text { olmak } \\
\text { isteyen çiftler } & (18-44 \\
\text { yaş arası kadın ve } \geq 18 \\
\text { yaş erkek) }\end{array}$ & $\begin{array}{l}\text { Gebeler: } 0,63 \mathrm{ng} / \mathrm{mL}^{\mathrm{f}} \\
\text { Gebe } \\
\text { olmayanlar:0,68 } \\
\mathrm{ng} / \mathrm{mL}^{\mathrm{f}}\end{array}$ & $\begin{array}{l}\text { Doğurganlık ve hamile kalma zamanı ile BFA } \\
\text { düzeyi arasında ilişki bulunmamıştır. }\end{array}$ \\
\hline Hiroi ve ark ${ }^{53}$ & $\begin{array}{l}\text { Endometriyal } \\
\text { rahatsızlıklar }\end{array}$ & Vaka-kontrol & 37 & $\begin{array}{l}\text { Endometriyal } \\
\text { hiperplazi olan ve } \\
\text { olmayan kontrol } \\
\text { grubu }\end{array}$ & $1,4-2,9 \mathrm{ng} / \mathrm{mL}^{\mathrm{d}}$ & $\begin{array}{l}\text { BFA maruziyeti ile endometriyal kanser ve } \\
\text { kompleks endometriyal hiperplazi arasında } \\
\text { ilişki bulunmuştur. }\end{array}$ \\
\hline Vitku ve ark ${ }^{60}$ & $\begin{array}{l}\text { Semen/sperm } \\
\text { kalitesi }\end{array}$ & Kohort & 191 & $\begin{array}{l}\text { Normospermik ve } \\
\text { normal olmayan } \\
\text { spermatojenezi } \\
\text { olanlar }\end{array}$ & $0,075-0,153 \mathrm{ng} / \mathrm{mL}^{\mathrm{g}}$ & $\begin{array}{l}\text { Seminal BFA düzeyi ile sperm } \\
\text { konsantrasyonu, sayısı ve morfolojisi } \\
\text { arasında negatif ilişki bulunmuştur. }\end{array}$ \\
\hline $\begin{array}{l}\text { Ehrlich ve ark } \\
34\end{array}$ & Fertilite & $\begin{array}{l}\text { Propektif } \\
\text { kohort }\end{array}$ & 137 & $\begin{array}{l}\text { IVF tedavisi altındaki } \\
\text { kadınlar }\end{array}$ & $1,53 \mu \mathrm{g} / \mathrm{L}^{\mathrm{a}}$ & $\begin{array}{l}\text { BFA düzeyi ile implantasyon başarısızlığ } \\
\text { arasında pozitif ilişki bulunmuştur. }\end{array}$ \\
\hline Rocca ve ark 26 & Fertilite & Kesitsel & 153 & $\begin{array}{l}\text { Gönüllü infertil ve } \\
\text { fertil erkekler }\end{array}$ & $4,8-10,6 \mathrm{ng} / \mathrm{mL}^{\mathrm{d}}$ & $\begin{array}{l}\text { Büyükşehirde yaşayan infertil erkeklerin } \\
\text { BFA seviyesi daha yüksek bulunmuştur. }\end{array}$ \\
\hline
\end{tabular}

FSH: folikül uyarıcı hormon; OV: yumurtalık hacmi; AFC: antral folikül sayısı; IVF: in vitro fertilizasyon; ICSI: Intrasitoplazmik sperm enjeksiyonu; FAI: serbest androjen indeks; FT: serbest testesteron; SHBG: cinsiyet hormonu bağlayan globülin. a: geometrik ortalama; idrar BFA düzeyi; b: $\mu$ g/g kreatine göre düzenlenmiş idrar BFA; c: medyan; d: serum BFA; e: özgül ağırlı̆ga göre düzenlenmiş idrar BFA; f: düzeltilmemiş idrar BFA; g: seminal BFA. 


\section{Kaynaklar}

1. Manfo FP, Jubendradass $R$, Nantia EA, Moundipa PF, Mathur PP. Adverse effects of Bisphenol A on male reproductive function. Rev environ contam Toxicol 2014;228:57-82.

2. Avissar-Whiting M, Veiga KR, Uhl KM,et al. Bisphenol A exposure leads to specific microrna alterations in placental cells. Reprod Toxicol 2010;29(4):401-406.

3. Tyl RW. Abbreviated assessment of Bisphenol A toxicology literature. Semin Fetal Neonatal Med 2014;19(3):195-202.

4. Hammer J, Kraak MH, Parsons JR. Plastics in the marine environment: the dark side of a modern gift. Rev Environ Contam Toxicol 2012;220:1-44.

5. Bhan A, Hussain I, Ansari KI, Bobzean SA, Perrotti LI, Mandal SS. Bisphenol-A and Diethylstilbestrol exposure induces the expression of breast cancer associated long noncoding rna hotair in vitro and in vivo. $J$ Steroid Biochem Mol Biol 2014;141:160-170.

6. Le Corre L, Besnard P, Chagnon MC. BPA, an energy balance disruptor. Crit Rev Food Sci Nutr 2015;55(6):769-777.

7. Vandenberg LN, Chahoud I, Heindel JJ, Padmanabhan V, Paumgartten FJ, Schoenfelder G. Urinary, circulating, and tissue biomonitoring studies indicate widespread exposure to Bisphenol A. Cien Saude Colet 2012;17(2):407-434.

8. Knez J. Endocrine-disrupting chemicals and male reproductive health. Reprod Biomed Online 2013;26(5):440-448.

9. Stahlhut RW, Welshons WV, Swan SH. Bisphenol A data in NHANES suggest longer than expected half-life, substantial nonfood exposure, or both. Environ Health Perspect 2009;117(5):784-789.

10. Geens T, Aerts D, Berthot C, et al. Review of dietary and non-dietary exposure to Bisphenol-A. Food Chem Toxicol: An International Journal Published for the British Industrial Biological Research Association 2012;50(10):3725-3740.

11. Volkel W, Colnot T, Csanady GA, Filser JG, Dekant W. Metabolism and kinetics of Bisphenol $\mathrm{A}$ in humans at low doses following oral administration. Chem Res Toxicol 2002;15(10):1281-1287.

12. Ginsberg G, Rice DC. Does rapid metabolism ensure negligible risk from Bisphenol A Environ Health Perspect 2009;117(11):1639-1643.

13. Fung EY, Ewoldsen NO, St Germain $\mathrm{HA}$, et al. Pharmacokinetics of Bisphenol A released from a dental sealant. J Am Dent Assoc 2000;131(1):51-58.

14. Schonfelder G, Wittfoht W, Hopp H, Talsness CE, Paul M, Chahoud I. Parent Bisphenol A accumulation in the human maternal-fetal-placental unit. Environ Health Perspect 2002;110(11):A703-707.

15. Vandenberg LN, Hauser R, Marcus M, Olea N, Welshons WV. Human exposure to Bisphenol A (BPA). Reprod Toxicol (Elmsford, N.Y.) 2007;24(2):139-177.

16. Matsumoto J, Yokota H, Yuasa A. Developmental increases in rat hepatic microsomal UDP-Glucuronosyltransferase activities toward xenoestrogens and decreases during pregnancy. Environ Health Perspect 2002;110(2):193.

17. EFSA. Opinion of the scientific panelon food additives, flavourings, processing aids and materials in contact with food on a request from the comission related to 2,2-bis(4-hydroxyphenyl) propane (Bisphenol A): The EFSA journal. 428:2006.; Question number EFSA-Q-2005100 adopted on

18. Vinas R, Jeng YJ, Watson CS. nongenomic effects of xenoestrogen mixtures. Int $J$ Environ Res Public Health 2012;9(8):2694-2714.

19. Bonefeld-Jorgensen EC, Long M, Hofmeister MV, Vinggaard AM. endocrinedisrupting potential of Bisphenol A, Bisphenol A Dimethacrylate, 4-NNonylphenol, and 4-N-Octylphenol in vitro: New data and a brief review. Environ Health Perspect 2007;115 Suppl 1:69-76.

20. Vom Saal FS, Akingbemi BT, Belcher SM, et al. Chapel hill Bisphenol A expert panel consensus statement: integration of mechanisms, effects in animals and potential 
to impact human health at current levels of exposure. Reprod Toxicol (Elmsford, NY) 2007;24(2):131.

21. Crain DA, Eriksen M, Iguchi T, et al. An ecological assessment of Bisphenol-A: Evidence from comparative biology. Reprod Toxicol (Elmsford, N.Y.) 2007;24(2):225-239.

22. Rochester JR. Bisphenol A and human health: A review of the literature. Reprod Toxicol 2013;42:132-155.

23. Damario MA. General aspects of fertility and infertility. Methods Mol Biol (Clifton, N.J.) 2014;1154:3-23.

24. Huo X, Chen D, He Y, Zhu W, Zhou W, Zhang J. Bisphenol-A and female infertility: A possible role of gene-environment interactions. Int J Environ Res Public Health 2015;12(9):11101-11116.

25. Meeker JD, Ehrlich S, Toth TL, et al. Semen quality and sperm DNA damage in relation to urinary Bisphenol A among men from an infertility clinic. Reprod Toxicol (Elmsford, N.Y.) 2010;30(4):532-539.

26. La Rocca C, Tait S, Guerranti C, et al. Exposure to endocrine disruptors and nuclear receptors gene expression in infertile and fertile men from Italian areas with different environmental features. Intl $J$ Environ Res Public Health 2015;12(10):12426-12445.

27. Caserta D, Bordi G, Ciardo F, et al. The influence of endocrine disruptors in a selected population of infertile women. Gynecol Endocrinol: The official journal of the International Society of Gynecological Endocrinology 2013;29(5):444-447.

28. Souter I, Smith KW, Dimitriadis I, et al. The association of Bisphenol-A urinary concentrations with antral follicle counts and other measures of ovarian reserve in women undergoing infertility treatments. Reprod Toxicol (Elmsford, N.Y.) 2013;42:224231.

29. Ehrlich S, Williams PL, Missmer SA, et al. Urinary Bisphenol A concentrations and early reproductive health outcomes among women undergoing ivf. Human Reproduction (Oxford, England) 2012;27(12):3583-3592.
30.

Bloom MS, Kim D, Vom Saal FS, et al. Bisphenol A exposure reduces the estradiol response to gonadotropin stimulation during in vitro fertilization. Fertil Steril 2011;96(3):672-677.e672.

31. Mok-Lin E, Ehrlich S, Williams PL, et al. Urinary Bisphenol A concentrations and ovarian response among women undergoing ivf. Int J Androl 2010;33(2):385-393.

32. Minguez-Alarcon L, Gaskins AJ, Chiu $\mathrm{YH}$, et al. Urinary Bisphenol A concentrations and association with in vitro fertilization outcomes among women from a fertility clinic. Human Reproduction (Oxford, England) 2015;30(9):2120-2128.

33. Louis GMB, Sundaram R, Sweeney AM, Schisterman EF, Maisog J, Kannan K. Urinary Bisphenol A, phthalates, and couple fecundity: The longitudinal investigation of fertility and the environment (LIFE) Study. Fertil Steril 2014;101(5):1359-1366.

34. Ehrlich S, Williams PL, Missmer SA, et al. Urinary Bisphenol A concentrations and implantation failure among women undergoing in vitro fertilization. Environ Health Perspect 2012;120(7):978.

35. Li DK, Zhou Z, Miao M, et al. Relationship between urine Bisphenol-A level and declining male sexual function. $J$ Androl 2010;31(5):500-506.

36. Liu X, Miao M, Zhou Z, et al. Exposure to Bisphenol-A and reproductive hormones among male adults. Environ Toxicol Pharmacol 2015;39(2):934-941.

37. Zoeller RT, Bansal R, Parris C. Bisphenol-A, an environmental contaminant that acts as a thyroid hormone receptor antagonist in vitro, increases serum thyroxine, and alters RC3/Neurogranin expression in the developing rat brain. Endocrinology 2005;146(2):607-612.

38. Mathur P, Saradha B, Vaithinathan S. Impact of environmental toxicants on testicular function. Immunol Endocr Metab Agents Med Chem (Formerly Curr Med Chem Immunol Endocr Metab Agents) 2008;8(1):79-90.

39. Goldstone AE, Chen Z, Perry MJ, Kannan K, Louis GM. Urinary Bisphenol A 
and semen quality, the life study. Reprod Toxicol (Elmsford, N.Y.) 2015;51:7-13.

40. Knez J, Kranvogl R, Breznik BP, Voncina E, Vlaisavljevic V. Are urinary Bisphenol A levels in men related to semen quality and embryo development after medically assisted reproduction? Fertil Steril 2014;101(1):215-221.E215.

41. Monje L, Varayoud J, Muñoz-de-Toro M, Luque E, Ramos J. Exposure of neonatal female rats to Bisphenol A disrupts hypothalamic LHRH Pre-Mrna processing and estrogen receptor alpha expression in nuclei controlling estrous cyclicity. Reproductive Toxicology 2010;30(4):625634.

42. Sharpe RM. Hormones and Testis development and the possible adverse effects of environmental chemicals. Toxicol Lett 2001;120(1-3):221-232.

43. Wilson JD. Sexual differentiation. Annu Rev Physiol 1978;40:279-306.

44. Meeker JD, Calafat AM, Hauser R. Urinary Bisphenol A concentrations in relation to serum thyroid and reproductive hormone levels in men from an infertility clinic. Environ Sci Technol 2010;44(4):14581463.

45. Mendiola J, Jorgensen N, Andersson $\mathrm{AM}$, et al. Are environmental levels of Bisphenol A associated with reproductive function in fertile men? Environ Health Perspect 2010;118(9):1286-1291.

46. Tarantino G, Valentino R, Di Somma $\mathrm{C}$, et al. Bisphenol A in Polycystic Ovary Syndrome and its association with liverspleen axis. Clin Endocrinol 2013;78(3):447453.

47. Kandaraki E, Chatzigeorgiou A, Livadas S, et al. Endocrine disruptors and Polycystic Ovary Syndrome (PCOS): Elevated serum levels of Bisphenol A in women with PCOS. J Clin Endocrinol Metab 2011;96(3):E480-484.

48. Fernandez M, Bianchi M, Lux-Lantos V, Libertun C. Neonatal exposure to Bisphenol A alters reproductive parameters and gonadotropin releasing hormone signaling in female rats. Environ Health Perspect 2009;117(5):757-762.
49. Takeuchi T, Tsutsumi O, Ikezuki Y, Takai Y, Taketani Y. Positive relationship between androgen and the endocrine disruptor, bisphenol a, in normal women and women with ovarian dysfunction. Endocr J 2004;51(2):165-169.

50. Missmer SA, Hankinson SE, Spiegelman D, Barbieri RL, Michels KB, Hunter DJ. In utero exposures and the incidence of endometriosis. Fertil Steril 2004;82(6):1501-1508.

51. Cobellis L, Colacurci N, Trabucco E, Carpentiero C, Grumetto L. Measurement of Bisphenol A and Bisphenol B levels in human blood sera from healthy and endometriotic women. Biomed Chromatogr: BMC 2009;23(11):1186-1190.

52. Upson K, Sathyanarayana S, De Roos AJ, Koch HM, Scholes D, Holt VL. A population-based case-control study of urinary Bisphenol A concentrations and risk of endometriosis. Hum Reprod (Oxford, England) 2014;29(11):2457-2464.

53. Hiroi H, Tsutsumi O, Takeuchi T, et al. Differences in serum Bisphenol A concentrations in premenopausal normal women and women with endometrial hyperplasia. Endocr J 2004;51(6):595-600.

54. Cao XL, Perez-Locas C, Dufresne G, et al. Concentrations of Bisphenol $\mathrm{A}$ in the composite food samples from the 2008 Canadian total diet study in Quebec city and dietary intake estimates. Food Addit Contam Part A Chem Anal Control Expo Risk Assess 2011;28(6):791-798.

55. Baird DT, Collins J, Egozcue J, et al. Fertility and ageing. Hum Reprod Update 2005;11(3):261-276.

56. Mahalingaiah S, Meeker JD, Pearson $\mathrm{KR}$, et al. Temporal variability and predictors of urinary Bisphenol A concentrations in men and women. Environ Health Perspect 2008;116(2):173-178.

57. Krishnan AV, Stathis P, Permuth SF, Tokes L, Feldman D. Bisphenol-A: An estrogenic substance is released from polycarbonate flasks during autoclaving. Endocrinology 1993;132(6):2279-2286.

58. Newbold RR, Jefferson WN, PadillaBanks E. Prenatal exposure to Bisphenol A at 
environmentally relevant doses adversely affects the murine female reproductive tract later in life. Environ Health Perspect 2009;117(6):879-885.

59. Li D, Zhou Z, Qing D, et al. Occupational exposure to Bisphenol-A (BPA) and the risk of self-reported male sexual dysfunction. Hum Reprod (Oxford, England) 2010;25(2):519-527.
60. Vitku J, Heracek J, Sosvorova L, et al. Associations of Bisphenol $A$ and Polychlorinated Biphenyls with spermatogenesis and steroidogenesis in two biological fluids from men attending an infertility clinic. Environment International 2016;89:166-173. 